\title{
DR-52. SYNTHESIS OF PYRAZINAMIDE ANALOGUES
}

$\underline{\text { I. S. Kovalev }}^{1}$, A. I. Degraf ${ }^{1}$, S. Santra ${ }^{1}$, D. S. Kopchuk ${ }^{1,2}$, G. V. Zyryanov ${ }^{1,2}$, V. L. Rusinov ${ }^{1,2}$, O. N. Chupakhin ${ }^{1,2}$

${ }^{1}$ Ural Federal University of the first President of Russia B. N. Yeltsin, Mira St., 19, Yekaterinburg, 620002, Russia

${ }^{2}$ I. Ya. Postovsky Institute of Organic Synthesis UB RAS,

S. Kovalevskoy/Akademicheskaya St., 20/22, Yekaterinburg, 620990, Russia

E-mail: ekls85@yandex.ru

Pyrazine derivatives are of interest due to their luminescent properties and biological activity. In particular, the tuberculosis pyrazinamide can be noted. In this paper, we proposed convenient methods for obtaining its analogues.<smiles>CCOC(=O)c1nc(-c2ccccc2)c(-c2c[nH]c3ccccc23)nc1N</smiles><smiles>CCOC(=O)c1nc(-c2ccccc2)c[n+](OC)c1N</smiles><smiles>Nc1c(C(=O)N2CCCC2)nc(-c2ccccc2)c[n+]1[O-]</smiles>

This work was supported by the Russian Science Foundation (Ref. № 18-13-00365). 